J. Lake Sci.(湖泊科学), 2008, 20(6): 766-772

http://www.jlakes.org. E-mail: jlakes@niglas.ac.cn

(C)2008 by Journal of Lake Sciences

\title{
云南抚仙湖流域废弃磷矿区水污染现状*
}

\author{
冯慕华，潘继征，柯 凡，李文朝 \\ (中国科学院南京地理与湖泊研究所湖泊与环境国家重点实验室，南京 210008)
}

摘 要: 抚仙湖流域未进行生态修复的磷矿废弃地面积 $142 \times 10^{4} \mathrm{~m}^{2}$ ，对磷矿废弃地污染物流失量和区域内径流污染物含量进行 调查观测, 并提出磷矿废弃地水污染防治对策. 富磷矿石剖面和堆土场在风化作用和降雨淋溶作用下, 大量氟、磷等元素释放, 造成磷矿区内地表径流和地下渗流污染. 结合实测的磷矿废弃地面积和土柱淋溶实验得到的污染物淋溶量, 估算得到磷矿废弃 地每年 $\mathrm{F}$-和 TP 的淋溶流失量为 $60.65 \mathrm{t} / \mathrm{a}$ 和 $27.34 \mathrm{t} / \mathrm{a}$ ，随地表径流迁移进人抚仙湖的 $\mathrm{F}$ 和 TP 分别为 $22.58 \mathrm{t} / \mathrm{a}$ 和 $7.27 \mathrm{t} / \mathrm{a}$. 由此可见, 磷 矿开采是抚仙湖的一个持久污染源, 对湖泊营养化演变进程起了推动作用.

关键词: 抚仙湖流域; 磷矿; 氟; 磷; 流失

\section{Water pollution of post-mined lands in Lake Fuxian watershed in Yunnan Province}

FENG Muhua, PAN Jizheng, KE Fan \& LI Wenchao

(State Key Laboratory of Lake Science and Environment, Nanjing Institute of Geography and Limnology, Chinese Academy of Sciences, Nanjing 210008, P.R.China)

Abstract: The un-restored post-mined lands in Lake Fuxian watershed is large scale, potentially covering over $142 \times 10^{4} \mathrm{~m}^{2}$. The investigation of the amounts of pollutants releasing from mined lands and transporting by runoffs was conducted. The erosion and eluviation on exposed phosphrite layer and overburden the resulted in the releasing of fluoride and phosphorus and water polluting. The releasing and transporting amounts of pollutants were calculated according to the results of column leaching studies and acreages of exposed phosphrite layers and overburdens. The results showed that the amounts of fluoride and phosphorus releasing were $60.65 \mathrm{t} / \mathrm{a}$ and $27.34 \mathrm{t} / \mathrm{a}$, respectively, and the amounts of fluoride and phosphorus transported by surface runoffs were $22.58 \mathrm{t} / \mathrm{a}$ and $7.27 \mathrm{t} / \mathrm{a}$, respectively. In conclusion, phosphorus mining activity is an important non-point source of water contamination of Lake Fuxian.

Keywords: Lake Fuxian watershed; phosphorite mined lands; fluorine; phosphorus; losing process

抚仙湖是我国第二深水湖 ${ }^{[1]}$, 目前全湖平均水质仍处于湖库 I 类水标准. 抚仙湖流域蕴藏着丰富的磷 矿资源，自 1984 年以来开展了大规模的磷矿露天开采和磷化工开发,创造了较好的经济效益, 同时也造 成了磷矿开发区严重的生态破坏和流域性环境污染，直接危及抚仙湖. 磷矿开发主要集中在东北部山区 的代村河径流区和东大河径流区, 2005 年抚仙湖全湖水质调查结果表明, 磷矿开发造成抚仙湖北岸东段 (与代村河、东大河径流区接壤岸段)水质恶化, 湖水总磷指标已达到湖库 IV 类水标准. 磷矿是磷的巨大 赋存库, 磷矿开采加速了已沉积矿化的磷的释放、迁移、转化等地球化学过程, 对内陆水体乃至海洋的 磷输人和水体生态系统的营养水平具有重大影响. 抚仙湖流域磷矿开采区内矿渣废弃地的土壤抗侵蚀性 差, 水土流失严重 ${ }^{[2-3]}$; 相邻的滇池流域晋宁磷矿排土场的磷流失研究结果表明, 降雨淋溶造成排土场总 磷流失量巨大 ${ }^{[4]}$, 对地面水和地下水造成影响 ${ }^{\mathbb{D}}$; 四川清平地区由于磷矿废渣降雨淋溶的影响, 河流水质

* 国家自然科学基金项目(40603023)和中国科学院南京地理与湖泊研究所所长基金(0600211001)联合资助. 2007-10-23 收 稿; 2008-05-28 收修改稿. 冯慕华, 女, 1978 年生，博士; 副研究员; E-mail: mhfeng@niglas.ac.cn.

(1) 云南省环境科学研究所. “六五”国家科技攻关项目——“滇池地区磷资源的开发研究”第八分项“滇池地区磷资源开发的 环境影响研究”, 1985. 
和沉积物受到严重污染 ${ }^{[5]}$; 贵州洋水磷矿区的废石场因降雨作用, 产生的废水排人河道使洋水河水质恶 化 ${ }^{[6]}$. 但对于磷矿开发水污染产生机制的研究相当缺乏, 磷矿废弃地污染物流失对湖泊的污染情况仍是 未知.

本文对抗仙湖流域内磷矿废弃地污染物的淋溶情况和水污染现状进行调查研究, 并对磷矿废弃地 污染物的产生量进行估算，在此基础上提出磷矿废弃地污染防治对策，以期控制磷矿废弃地对抚仙湖 的污染.

\section{1 研究方法}

\section{1 现场调查与监测}

2005 年 9-11 月, 对 16 个磷矿开采点进行调查, 采用星站差分定位系统(NavCom SF-2050M/C) 对抗 仙湖流域的磷矿开采面积、排土场面积和开采深度进行勘测，同时在各个废弃磷矿点采集积水坑水样和 沉积物样进行分析, 污染物浓度反映了废土石和磷矿石在降雨淋溶作用下流失的污染物量.

分别于 2005 年 9 月和 2006 年 10 月两个雨季, 对抗仙湖流域磷矿开发区水污染现状进行调查. 沿着 磷矿开发区内两条河流代村河和东大河从上游到下游依次布设采样点，观测磷矿废弃地对地表水和地下 水造成污染程度. 对两条河流磷矿点所在的主要支流、支流汇人主河道的河口处以及水库的出、人口布 设采样点(图 1), 采集地表水和地下水水样, 其中代村河流域采集 7 个地表水样(编号代 1-代 7), 8 个地下 水样(编号代 s1-代 s8); 东大河流域 11 个地表水样(编号东 1-东 11), 6 个地下水样(编号东 s1-东 s6).

测定项目包括：水相中的总磷(TP)，可溶性总磷酸盐(TDP), 颗粒态磷(PP)，溶解态磷(DP)，氟离子 $\left(F^{-}\right)$; 沉积物样中的总磷. 测定方法为: 水样 $\mathrm{TP}$ (水样直接测定)、 $\mathrm{TDP}$ (水样经 $0.45 \mu \mathrm{m}$ 滤膜过滤后)采用过 硫酸钾氧化一钿锑抗分光光度法测定, DP(水样经 $0.45 \mu \mathrm{m}$ 滤膜过滤后) 采用钿锑抗分光光度法测定, PP 通 过差减法(TP-TDP)计算. F-含量测定采用离子选择性电极法. 沉积物总磷含量采用酸溶-锄锑抗分光光度 法测定 ${ }^{[7]}$.

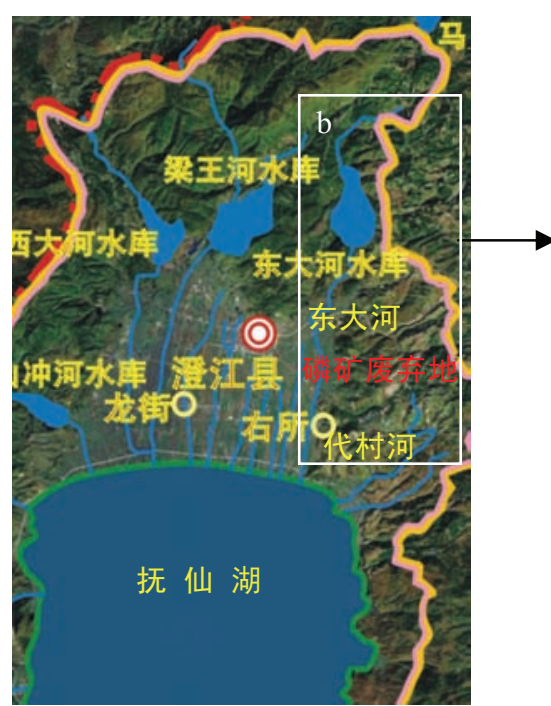

(a)

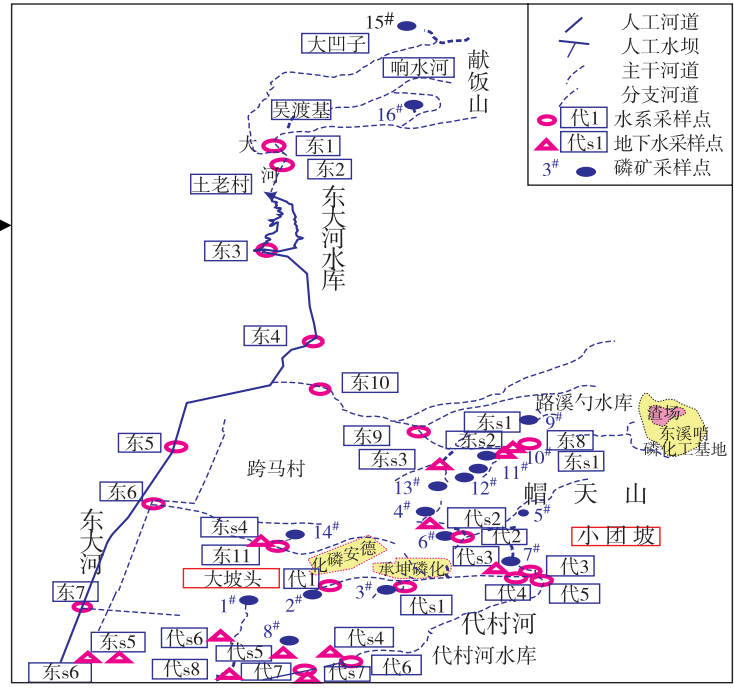

(b)

图 1 采样点分布

Fig.1 Map of sample sites

\section{2 淋溶实验}

取粒径为 $1 \mathrm{~mm}$ 的磷矿石和废土石样品进行土柱淋溶实验. 土柱淋溶试验具体步骤和装置与以前工 作相同 ${ }^{[8]}$, 土柱内径 $90 \mathrm{~mm}$, 填充高度 $300 \mathrm{~mm}$, 土柱内样品按磷矿区的实际堆积情况进行充填. 采用 
$0.01 \mathrm{~mol} / \mathrm{L} \mathrm{CaCl}_{2}$ 溶液作为淋溶液, 淋溶流速为 $0.1 \mathrm{~mm} / \mathrm{min}$, 累计淋溶量为 $951 \mathrm{~mm}$, 与抚仙湖流域帽天山 矿区的年降雨量相近 ${ }^{[9]}$. 淋溶过程按一定时间间隔收集淋滤液. 待出水恒定后开始计时取样, 每次取 $50 \mathrm{ml}$. 所得淋滤液在 $5000 \mathrm{r} / \mathrm{min}$ 下离心 $10 \mathrm{~min}$, 取上清液测定 $\mathrm{PO}_{4}{ }^{3-}$ 和 $\mathrm{F}^{-}$含量.

\section{2 结果与分析}

\section{1 磷矿废弃地现状}

抚仙湖流域蕴藏着丰富的高品位磷矿资源——澄江渔户村磷矿区，已开采了 16 个矿点(图 1), 目前 这些矿点已全部停采. 对抚仙湖流域的磷矿开采面积、排土场面积和开采深度进行勘测结果见表 1. 磷矿 山开采地表破坏总面积达到 $142 \times 10^{4} \mathrm{~m}^{2}$, 最小开采面积 $0.95 \times 10^{4} \mathrm{~m}^{2}$, 最大为 $25 \times 10^{4} \mathrm{~m}^{2}$; 采矿深度最小 为 $14 \mathrm{~m}$, 最大达到 $114 \mathrm{~m}$. 开采剥离下来的覆土和围岩及低品位矿石堆积所形成的废弃地, 土壤贫㾑, 复 星率低, 抚仙湖流域矿山植被恢复率仅有 $13.3 \%$. 大面积磷矿废弃地和富磷矿层剖面裸露出地表, 改变了 环境污染物质的原生环境, 环境污染物极易受外界条件影响而迁移出地壳层.

磷矿废弃地主要分布在代村河和东大河流域. 代村河流域分布着 8 个磷矿点 $\left(1^{\#}-8^{\#}\right)$, 开采面积共 $78.80 \times 10^{4} \mathrm{~m}^{2}$ (表 1$)$, 另有两个磷矿加工生产基地; 东大河流域也有 8 个磷矿点 $\left(9^{\#}-16^{\#}\right)$, 开采面积为 63.49 $\times 10^{4} \mathrm{~m}^{2}$ (表 1$)$, 其中东大河水库上游 2 个磷矿点 $\left(15^{\#}, 16^{\#}\right)$. 磷矿废弃地流失的污染物通过这两条河流由东 北方向进入抚仙湖.

表 1 抚仙湖流域磷矿开采地表破坏现状

Tab.1 Status of post-mined lands in Lake Fuxian watershed

\begin{tabular}{ccccccc}
\hline 编号 & 矿山地名 & $\begin{array}{c}\text { 总面积 } \\
\left(\times 10^{4} \mathrm{~m}^{2}\right)\end{array}$ & $\begin{array}{c}\text { 开采面积 } \\
\left(\times 10^{4} \mathrm{~m}^{2}\right)\end{array}$ & $\begin{array}{c}\text { 排土场 } \\
\left(\times 10^{4} \mathrm{~m}^{2}\right)\end{array}$ & $\begin{array}{c}\text { 深度 } \\
(\mathrm{m})\end{array}$ & $\begin{array}{c}\text { 开采 } \\
\text { 情况 }\end{array}$ \\
\hline $1^{\#}$ & 磨盘山西 & 7.07 & 2.48 & 4.25 & 107 & 停采 \\
$2^{\#}$ & 磨盘山东 & 18.59 & 5.81 & 10.50 & 114 & 停采 \\
$3^{\#}$ & 大坡头 & 4.04 & 1.21 & 2.83 & 87 & 停采 \\
$4^{\#}$ & 空心坟 & 25.24 & 14.40 & 10.84 & 101 & 停采 \\
$5^{\#}$ & 倮俚山 & 8.73 & 2.42 & 6.30 & 57 & 停采 \\
$6^{\#}$ & 空心坟 & 11.82 & 4.44 & 7.38 & 80 & 停采 \\
$7^{\#}$ & 小团坡 & 0.95 & 0.20 & 0.75 & 14 & 停采 \\
$8^{\#}$ & 红家冲 & 2.36 & 1.40 & 0.96 & 55 & 停采 \\
$9^{\#}$ & 郭家山 & 19.08 & 7.56 & 11.51 & 92 & 停采 \\
$10^{\#}$ & 崆峒山 & 7.83 & 2.40 & 5.43 & 93 & 停采 \\
$11^{\#}$ & 崆峒山 & 9.97 & 3.90 & 6.07 & 52 & 停采 \\
$12^{\#}$ & 崆峒山 & 6.16 & 1.87 & 4.30 & 53 & 停采 \\
$13^{\#}$ & 空心坟 & 10.31 & 7.39 & 2.93 & 78 & 停采 \\
$14^{\#}$ & 旧城大山 & - & - & - & 已恢复 \\
$15^{\#}$ & 大山子 & 5.72 & 2.82 & 2.90 & 59 & 在采 \\
$16^{\#}$ & 献饭山 & 4.42 & 1.79 & 2.63 & 85 & 停采 \\
& 合计 & 142.29 & 60.09 & 79.58 & & \\
\hline
\end{tabular}

\section{2 磷矿废弃地磷、氟流失情况}

磷矿开采造成矿山成漏斗形矿坑，降雨淋溶排土场和未开采完的矿层剖面，在矿坑中形成积水，采 集矿坑水样和沉积物样进行分析, 结果见图 2. 排土场积水坑采集的样品编号为 $1^{\#}-4^{\#}$ 和 $9^{\#}-12^{\#}$, 富磷矿 层剖面下积水坑采集的样品编号为 $8^{\#} 、 13^{\#}$ 和 $15^{\#}$, 其它矿点未采到样品. 排土场积水坑中积水呈酸性, $\mathrm{pH}$ 均小于 6 , 其中 $2^{\#} 、 9^{\#}$ 和 $11^{\#}$ 积水坑水样 $\mathrm{pH}<3$, 这是由于露天采矿开挖出来的还原性硫化物、煤层及页岩 层因自然氧化而形成酸性物质, 在降雨淋溶作用下形成酸性溶液. 水样 TP 含量差异很大, 变幅为 
0.67-9.04mg/L, F-含量在 4.28- $12.34 \mathrm{mg} / \mathrm{L}$ 内变化. 水样和沉积物中污染物含量差异大与排土场物质组成 差异有关. 当地采矿方式粗放, 大量低品位磷矿石被抛弃，和酸性废土石混杂堆放形成排土场，降雨形 成的酸性淋溶液对混杂其中的磷矿石直接产生酸溶作用. 以 $9^{\#}$ 矿点为例, 排土场积水坑水样 $\mathrm{pH}$ 值仅为 $2.72, \mathrm{TP}$ 高达 $9.04 \mathrm{mg} / \mathrm{L}$, 并以溶解态磷为主, $\mathrm{F}^{-}$含量为 $10.97 \mathrm{mg} / \mathrm{L}$, 这主要是由于废土石产生的酸性溶液对 低品位磷矿石污染物淋溶作用很强, 释放出大量的 P、F 元素. 磷矿层剖面下方积水坑 $\left(8^{\#} 、 13^{\#}\right.$ 和 $\left.15^{\#}\right)$ 采 集的水样 TP 含量达到 1.76-5.74mg/L, 是地表水环境质量 V 类标准 $(\leqslant 0.4 \mathrm{mg} / \mathrm{L}, \mathrm{GB} 3838-2002)$ 的 4-14 倍, 并且以 $\mathrm{PP}$ 为主, 占 $\mathrm{TP}$ 的 $75 \%$ 以上; $\mathrm{F}^{-}$含量最高为 $10.02 \mathrm{mg} / \mathrm{L}$, 是地表水 $\mathrm{V}$ 类标准 $(\leqslant 1.5 \mathrm{mg} / \mathrm{L}$, GB3838-2002)的 5 倍.

排土场积水坑沉积物 TP 含量变化范围为 $2.68-30.97 \mathrm{~g} / \mathrm{kg}$, 磷矿层剖面下方积水坑沉积物 TP 含量为 $11.99-28.84 \mathrm{~g} / \mathrm{kg}$. 资料表明, 我国土壤的 TP 含量变幅大约在 $0.17-1.09 \mathrm{~g} / \mathrm{kg}$ 之间 ${ }^{[10]}$; 抚仙湖流域农田表层 土壤 TP 为 $0.8 \mathrm{~g} / \mathrm{kg}$, 未耕作土壤 $\mathrm{TP}$ 为 $0.4 \mathrm{~g} / \mathrm{kg}^{[11]}$. 与该地区土壤背景值 $0.4 \mathrm{~g} / \mathrm{kg}$ 相比较 ${ }^{[11]}$, 矿山积水坑中 沉积物含量高出 5-70 倍, 比我国普通土壤 TP 的最高值 ${ }^{[9]}$ 高一个数量级. 磷矿废弃地积水坑中水样和沉 积物样磷含量高, 这是由于富磷矿层受到风化淋溶作用, 大量磷迁移进人外界环境. 磷矿区地处亚热带 高原气候, 雨季降雨充沛和旱季风力强劲, 物理风化作用较强, 出露地表的钙质磷灰石极易被风化成碎 屑状. 此外，该地区容易产生酸性沉降，使磷矿石的化学风化过程加剧. 位于东北方向的磷矿加工区排 放的强酸性废气、粉尘在主导风向西南风的作用下，易于向磷矿开采区方向扩散，形成酸性干、湿沉降; 而且矿山的表层覆土属于酸性红壤, 坡面酸性漫流对出露地表的磷矿具有很强的淋溶能力. 酸化作用对 磷灰石产生化学风化过程: $6 \mathrm{H}^{+}+\mathrm{Ca}_{5}\left(\mathrm{PO}_{4}\right)_{3} \mathrm{~F}=5 \mathrm{Ca}^{2+}+3 \mathrm{H}_{2} \mathrm{PO}_{4}^{-}+\mathrm{F}$, 这一过程中磷灰石稳定的磷酸钙转化为 易于迁移的磷酸氢盐, 并释放出氟.

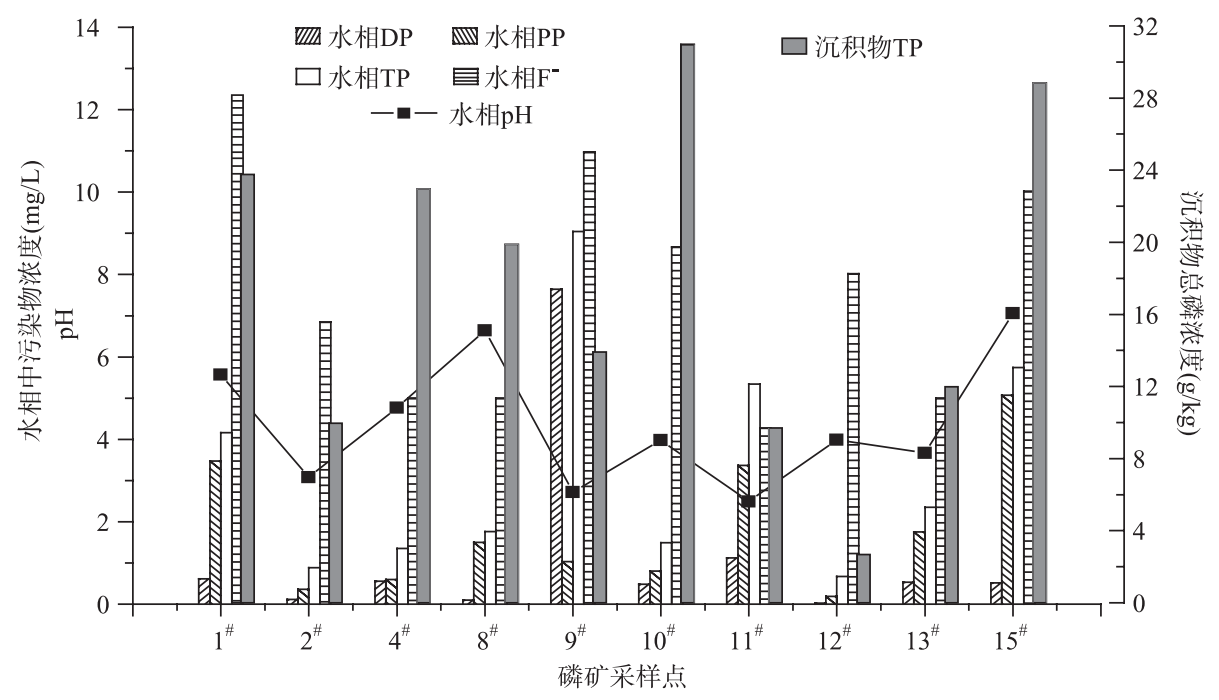

图 2 采矿点积水坑水样和底泥样污染物分析

Fig.2 Pollutants in waters and soils sampling from mine pits

\section{3 废弃磷矿区的磷流失对水环境影响}

磷矿废弃地产生的污染物主要通过东大河和代村河进人抚仙湖, 对东大河和代村河流域的地表水和 地下水 TP 含量进行分析. 东大河地表水 TP 含量变化很大, 变化范围为 $0.014-0.607 \mathrm{mg} / \mathrm{L}$ (图 3a), 最小值 出现在东大河水库(东 3 ), 而在东大河水库上游(东 2 ), 水体 $\mathrm{TP}$ 浓度为 $0.25 \mathrm{mg} / \mathrm{L}$ ，超过地表水 $\mathrm{III}$ 类水质标 准(GB3838-2002). 东大河水库上游有 2 个磷矿点, 上游地处山区, 没有农田耕作, 水体污染物主要来源 于磷矿开采. 下游河道水样(东 5-东 11)TP 含量 $0.435-16.97 \mathrm{mg} / \mathrm{L}$, 均超过地表水环境质量 $\mathrm{V}$ 类标准 (GB3838-2002), 其中东 8 和东 $11 \mathrm{TP}$ 含量分别达到 7.14 和 $16.97 \mathrm{mg} / \mathrm{L}$, 这是由于汇人下游河道的支流流域 
有大量磷矿开采点和磷化工企业, 造成水体严重污染。矿点附近采集的地下水浓度范围为 0.258- $1.41 \mathrm{mg} / \mathrm{L}$, 由于 $\mathrm{P}$ 尚未列入地下水水质质量监测项目, 根据地表水环境质量 $\mathrm{III}$ 类标准 $(\mathrm{TP}$ 浓度参 考标准 $\leqslant 0.2 \mathrm{mg} / \mathrm{L}, \mathrm{GB} 3838-2002)^{[11]}$, 地下水 TP 含量均超标. 磷矿开发产生的污染物进人地下水, 使地下 水受到污染.

代村河流域采集的地表水 TP 含量变化范围为 0.44-22.9mg/L(图 3b), 磷污染现象较为严重. 代村河 流域内 8 个磷矿开采点临近主河道, 分布较为集中; 而且代村河流域分布着两个磷化工企业, 磷矿加工 过程产生的废土石、废渣随意堆放，水土流失严重，直接对水环境造成污染，同时酸性粉尘还能促进附近 的磷矿山污染物释放. 磷矿开采迹地的高品位磷矿层和废土石污染物淋溶造成代 1 、代 2 和代 3 采样点 水体中 TP 含量 $0.44-1.27 \mathrm{mg} / \mathrm{L}$, 超过地表水 $\mathrm{V}$ 类水质标准(GB3838-2002). 由于磷石膏堆渣场产生大量的 酸性淋溶废水进入代村河河道, 代 4 和代 5 水样 $\mathrm{pH}$ 仅为 3.5 , TP 含量分别达到 24.6 和 $22.9 \mathrm{mg} / \mathrm{L}$. 由于磷 矿废弃地和堆渣场的影响, 造成代村河水库(代 6)TP 达到 $11.61 \mathrm{mg} / \mathrm{L}$, 是湖、库 $\mathrm{V}$ 类水质标准 (GB3838-2002)的 50 倍; 代村河下游水体(代 7)TP $10.73 \mathrm{mg} / \mathrm{L}$, 是地表水 $\mathrm{V}$ 类水质标准(GB3838-2002)的 25 倍. 代村河流域地下水 TP 含量变化幅度为 $0.165-1.86 \mathrm{mg} / \mathrm{L}$, 表明磷矿废弃地淋溶废水已对部分区域地 下水造成污染.
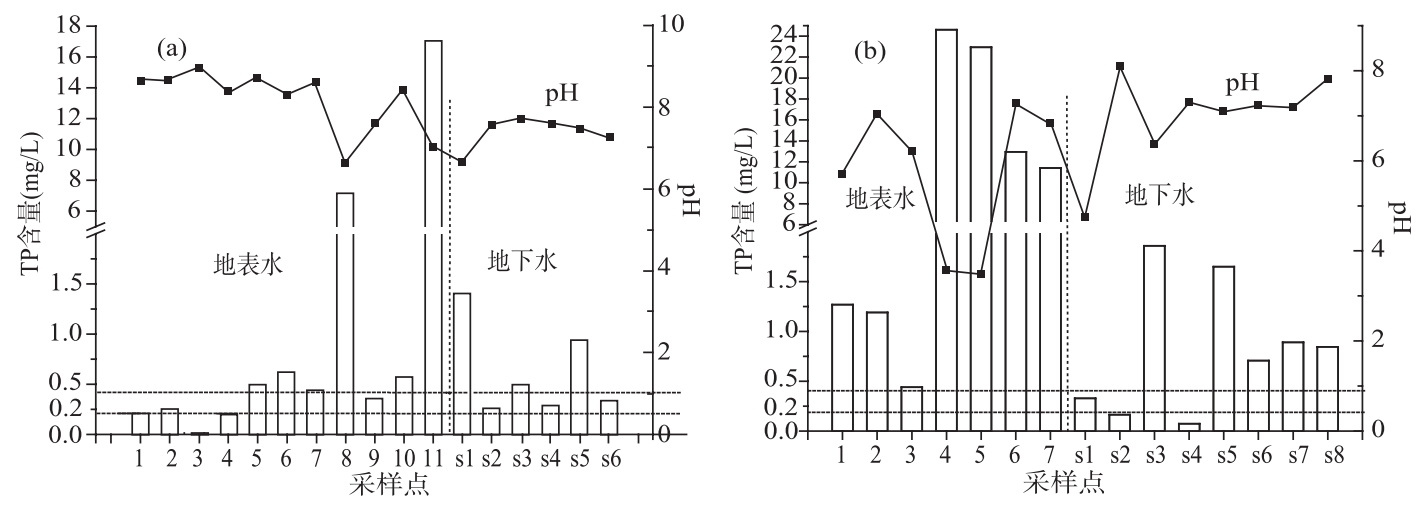

图 3 东大河(a)和代村河(b)流域地表水和地下水 TP 含量

Fig.3 Phosphorus contents in surface and subsurface runoffrs in Dongdahe stream (a) and Daicunhe stream (b)

\section{4 废弃磷矿区污染负荷估算与分析}

为估算废土石堆场和磷矿石剖面污染物流失量, 采用土柱淋溶实验模拟废弃磷矿区污染物释放动态 过程. 经过模拟降雨淋溶 $8 \mathrm{~h}$ 后, 废土石和磷矿石 $\mathrm{TP}$ 和 $\mathrm{F}$-的淋溶量趋于稳定, 以达到恒定后淋溶液 P、F 浓度来估算污染物流失量, 得到废土石 $\mathrm{TP}$ 和 $\mathrm{F}^{-}$的淋溶量分别为 $0.55 \mathrm{mg} / \mathrm{L}$ 和 $1.22 \mathrm{mg} / \mathrm{L}$, 磷矿石 $\mathrm{TP}$ 和 $\mathrm{F}^{-}$ 的淋溶量分别为 $0.71 \mathrm{mg} / \mathrm{L}$ 和 $1.37 \mathrm{mg} / \mathrm{L}$ (图 4). 抚仙湖流域多年平均降雨量为 $951 \mathrm{~mm} / \mathrm{a}^{[9]}$, 陆面径流系数为 $0.395^{[12]}$, 根据星站差分定位系统(NavCom SF-2050M/C) 对矿山废弃地的勘测结果(表 1), 得到堆土场总体 积 $2245 \times 10^{4} \mathrm{~m}^{3}$ 和裸露的磷矿石剖面总体积 $1725 \times 10^{4} \mathrm{~m}^{3}$. 以此为基础估算废弃磷矿区 $\mathrm{P} 、 \mathrm{~F}$ 淋溶流失量:

$$
\text { 污染物流失总量 }=\frac{\text { 土柱淋溶面积 } x \text { 年降水量 } \times \text { 径流系数 } \times \text { 溶出浓度 }}{\text { 土柱淋溶体积 }} \times \text { 弃地淋溶体积 }
$$

据此估算得到磷矿废弃地废土石堆场每年淋溶出 $\mathrm{TP}$ 为 $15.46 \mathrm{t}$ 和 $\mathrm{F}$-为 $34.30 \mathrm{t}$, 裸露的富磷矿石层每年 淋溶出 $\mathrm{TP}$ 和 $\mathrm{F}^{-}$分别为 $11.88 \mathrm{t}$ 和 $26.35 \mathrm{t}$. 这是根据富磷矿石剖面和堆土场的面积和单一淋溶条件下的淋溶 量进行计算, 没有考虑实际的降雨量、坡面产流量、沙土流失量以及其它淋溶作用如酸性淋溶、风化、 微生物作用等, 模拟值比实际测得的矿坑积水中污染物含量低, 但对磷矿废弃地污染物淋溶量的初步估 算结果可以得到废弃磷矿山裸露的磷矿层和堆土场每年都产生大量 P、F 流失, 这个流失过程是持久的.

磷矿废弃地淋溶的 P、F 究竟有多少通过地下渗流和地表径流等途径增加抗仙湖的污染负荷, 需根据 
地表水和地下水输送的污染物含量进行估算. 由于缺乏该区域地下渗流的水文资料, 只对地表径流携带 污染物量进行分析. 磷矿废弃地主要地表径流为东大河和代村河, 这两条河流多年平均径流量分别为 $2065.4 \times 10^{4} \mathrm{~m}^{3} / \mathrm{a}$ 和 $479.6 \times 10^{4} \mathrm{~m}^{3} / \mathrm{a}$ (玉溪市环境监测站, 抚仙湖流域水系分布图, 2004). 以磷矿废弃地污 染物输人为主、受农业生产和化工生产影响较小的上游径流污染物含量作为从磷矿废弃地流失进人地表 径流的污染物量, 东大河(东 2) TP 和 $\mathrm{F}^{-}$分别为 $0.25 \mathrm{mg} / \mathrm{L}$ 和 $0.55 \mathrm{mg} / \mathrm{L}$, 代村河(代 3) $\mathrm{TP}$ 和 $\mathrm{F}^{-}$分别为 $0.44 \mathrm{mg} / \mathrm{L}$ 和 $2.34 \mathrm{mg} / \mathrm{L}$. 可以得到磷矿废弃地流失的 $\mathrm{P}$ 和 $\mathrm{F}$ 通过东大河输移分别为 $5.16 \mathrm{t} / \mathrm{a}$ 和 $11.36 \mathrm{t} / \mathrm{a}$, 通过代村河 输移分别为 $2.11 \mathrm{t} / \mathrm{a}$ 和 11.22t/a, 两条河流输送的 P 和 F 分别占磷矿废弃地 $\mathrm{P}$ 和 F 淋溶量的 $26.6 \%$ 和 $37.2 \%$. 由此可以得到淋溶的 $\mathrm{P}$ 和 $\mathrm{F}$ 仅有部分随地表径流迁移出磷矿废弃地, 大部分滞留废弃地参与沉积、矿化、 植物吸收、微生物降解等生物地球化学过程或进人地下渗流中进行迁移.
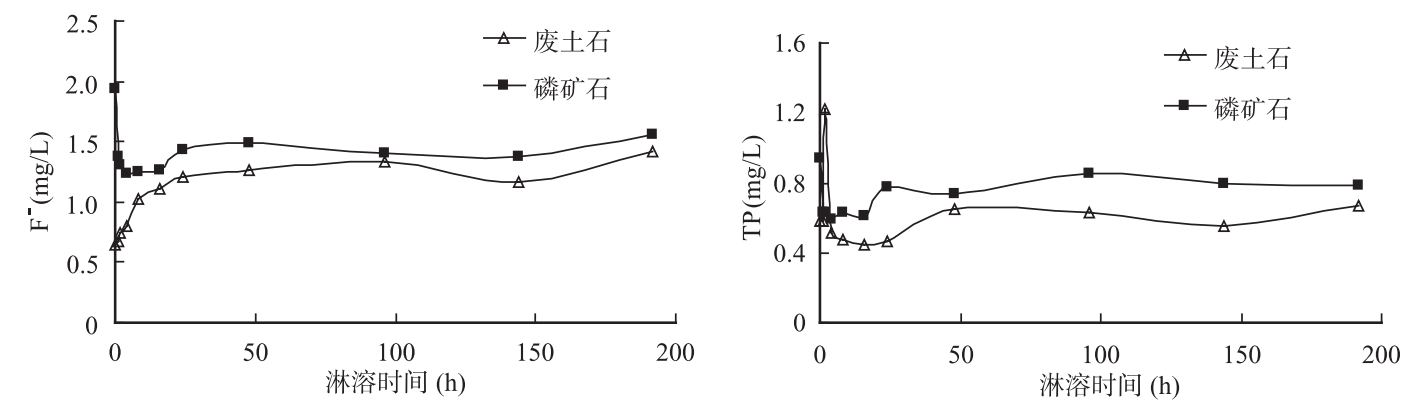

图 4 废土石和磷矿石 $\mathrm{F}^{-}$和 $\mathrm{TP}$ 释放特征

Fig.4 Release characteristic of $\mathrm{F}^{-}$and TP from overburden and phosphrite

\section{5 磷矿废弃地污染防治对策}

对磷矿废弃地污染物流失情况分析结果表明, 裸露的磷矿层和堆土场每年都产生大量 P、F 流失, 而 且这个流失过程是持久的. 但是按照常规的回填-覆土-植被恢复治理方法实施废弃磷矿治理, 能否有效 防止污染尚不得而知. 酸性废土石回填掩埋后, 酸性溶液下渗淋溶浸泡仍能使没有上覆岩层保护的大面 积高品位磷矿床发生污染物流失和地下水污染. 花费巨资作常规的回填-覆土一植被恢复 ${ }^{[13]}$ 治理不仅解决 不了废弃磷矿污染问题, 还有可能加剧污染. 目前矿山修复都没有进行环境风险评估 ${ }^{[14-16]}$, 矿山的污染 问题没有得到彻底解决，矿山修复亟需探索一条与污染治理相结合的新路子. 根据这一思路，我们提出 了 “地形钝化改造-表层基质无毒化改造-保水覆土改造-植被修复-废水收集处理” 废弃磷矿地环境整治 与生态修复方案:

(1)地形钝化改造：通过对采矿迹地的挖、填、平整，创建接近于自然的次生地貌和水文模式.

（2)表层基质无毒化改造: 对有生物毒性、有可能影响生态修复的渣土实施原位深埋处理，对易风化 淋溶的高品位磷矿床剖面采用挂网喷射混凝土密封保护.

(3)保水覆土改造: 必须覆盖一定厚度的土壤, 才有可能建立适当的植被. 在坡度较大的坡面, 需要 采取特殊技术进行覆土和保水; 对于掩埋有毒渣土的地段, 须考虑防止雨水淋溶和径流人侵措施.

(4)植被修复：依据地形、底质条件和周边生态景观, 选定适当的目标植被进行生态修复.

(5)废弃地废水收集处理: 设置富磷淋溶废水拦截工程, 收集矿区排出的地表径流和浅层地下渗流, 利用湿地净化系统处理污染废水.

通过对磷矿废弃地进行污染治理, 对污染废水进行拦截处置, 将有效控制磷矿废弃地污染物流失造 成的流域性环境污染，控制磷矿废弃地对抚仙湖的污染输人.

\section{3 结论}

通过磷矿废弃地污染物淋溶量和该区域地表径流和地下渗流污染物含量调查分析, 磷矿废弃地裸露 的富磷矿层和堆土场极易发生风化淋溶, 造成 P、F 元素流失, 磷矿废弃地积水坑 P 和 F 含量达到 9.04 
和 $12.34 \mathrm{mg} / \mathrm{L}$ ，是该区域地表水和地下水中高浓度 $\mathrm{P}$ 和 $\mathrm{F}$ 的主要来源.

为了估算磷矿废弃地污染物产生量和迁移量, 结合测量得到的磷矿废弃地裸露的矿石层剖面面积和 堆土场坡面积, 以及矿石和废土石污染物淋溶量, 得到磷矿废弃地 $\mathrm{P}$ 和 $\mathrm{F}$ 的淋溶流失量分别达到 27.34t/a 和 60.65t/a，但随地表径流迁移的 P 和 $\mathrm{F}$ 为 $7.27 \mathrm{t} / \mathrm{a}$ 和 $22.58 \mathrm{t} / \mathrm{a}$ ，占总淋溶流失量的 $27 \%$ 和 $37 \%$. 下一步将 对淋溶出地壳层的 $\mathrm{P}$ 和 $\mathrm{F}$ 元素的生物地球化学循环过程和归宿进行研究, 以探究最终迁移出废弃地的污 染物含量, 从而估算磷矿废弃地对抚仙湖的污染负荷.

\section{4 参考文献}

[1] 王苏民, 窦鸿身. 中国湖泊志. 北京: 科学出版社, 1998.

[2] 张建萍, 杨树华, 王宝荣. 抚仙湖流域磷矿区主要植物群落水土保持效应研究. 西部林业科学, 2004, 33(2): 76-80.

[3] 杨礼攀, 王宝荣, 杨树华. 抚仙湖流域区磷矿开采废弃地植物群落演替的研究. 西部林业科学, 2004, 33(1): 94-100.

[4] 汤承涁. 晋宁磷矿排土场磷流失模拟研究. 云南环境科学, 1996, 15(2): 7-11.

[5] 施为光, 杨菊仙. 四川省清平地区磷矿废渣对水体的影响研究. 农村生态环境, 1997, 13(2): 21-24.

[6] 汤贤勇. 开阳磷矿洋水矿区矿山开采与环境综合治理. 贵州地质, 2001, 18(1): 64-67.

[7] 鲁如坤. 土壤农业化学分析方法. 北京: 中国农业科技出版社, 2000.

[8] 冯慕华, 郑 锦, 李文朝等. 云南抚仙湖流域帽天山磷矿区磷流失过程模拟研究. 环境化学, 2007, 26(6): 801-804.

[9] 中国科学院南京地理与湖泊研究所. 抚仙湖. 北京: 海洋出版社, 1990.

[10] 卢 瑛, 龚子同, 张甘霖. 城市土壤磷素特性及其与地下水磷浓度的关系. 应用生态学报, 2001, 12(5): 735-738.

[11] 夏天翔, 李文朝, 潘继征. 抚仙湖流域不同农业模式砾质土壤环境质量及其氮磷流失风险评估. 湖泊科学, 2008, 20(1): 110-116.

[12] 徐金涛, 张 奇, 徐力刚. 抚仙湖集水域地表径流人湖水量模拟. 湖泊科学, 2007, 19(6): 718-726.

[13] 李洪远, 鞠美庭主编. 生态修复的原理和实践. 北京: 化学工业出版社, 2005: 207-227.

[14] Brown MT. Landscape restoration following phosphate mining: 30 years of co-evolution of science, industry and regulation. Ecological Engineering, 2005, 24: 309-329.

[15] Li MS. Ecological restoration of mineland with particular reference to the metalliferous mine wasteland in China: A review of research and practice. Science of the Total Environment, 2006, 357: 38-53.

[16] Shu WS, Ye ZH, Lan CY et al. Acidification of lead/zinc mine tailings and its effect on heavy metal mobility. Environment International, 2001, 26: 389-394. 